response of blood donations during the hours and days following the events.

Keywords: blood; collection; components; distribution; donations; Israel; multicasualty events; processing; requirements; supplies; terrorist attacks

Prehosp Disast Med 2003;18(s1)s33.

\section{Impact of War: Reflections on Blood Transfusion Services in BiH 1992-2002}

Prof. Dr. Midhat Haracic

Zavod $\mathrm{Za}$ Tronsfuzijsku Medicinu FBiH

This presentation defines the basic problems with blood transfusion services in post-war Bosnia and Herzegovina. First, the pre-war context will summarised, then the situation during the war will be identified, and finally the postwar period will be examined. Comparisons between these three periods will highlight the impact of war on the organisation and function of blood transfusion institutions and services.

We explore difficulties in: (1) Motivating blood donors; (2) Setting one strategy for the whole country; (3) Developing common standards; (4) Having a lock on legislation, (5) The education and training of personnel; (6) Developing quality management and control; (7) The financing of services and institutions; (8) Having an increase in the demand for blood and blood components, but with fewer resources and an inefficient and ineffective country-wide organisation resulting in poor management.

Keywords: blood; Bosnia-Herzegovina; components, blood; demand; donors; education; effectiveness; efficiency; financing; legislation; management; quality; resources; standards; strategies; training; transfusion services; war

Prehosp Disast Med 2003;18(s1)s33.

\section{A Model of Medical Measures for Blood Transfusion Services for Mass Casualties \\ Azad Hajiyev, $M D$; Azer Kerimor, $M D$}

Research Institute of Hematology and Transfusion Medicine, Azerbaijan

All the services of a country's public health system should be capable of rendering assistance to people affected during natural or man-made disasters, war, or other large events. Adequate blood transfusions and maintenance of medical measures for large groups of the population is possible only if there is a sufficient group of specialists in blood transfusion medicine who possess methods for emergency care and methods for the use of blood and its components in extreme conditions.

Within the last several years, a model for constant readiness to provide blood transfusions has been developed, and includes the conditions required to process a large number of the donors after notification of the occurrence of a disaster. The laboratory component of the blood transfusion crew ensures control of the main specifications for clinical analysis, homeostasis, and virus safety of the donated blood. At the same time, maintenance of the blood transfusion service demands organization of medical and donor plasmapheresis, which, because of the absence of a mobile point for donor plasmapheresis, currently is not being supplied up to an adequate level. For example, an injured person may require at least 1 liter of frozen plasma per day and $250 \mathrm{ml}$ of packed red blood cells. Plasmapheresis is also necessary at the early stages of the development of acute renal failure, which may result following trauma-induced injuries.

Thus, the service of providing adequate blood transfusion services in Azerbaijan is in the formative stages (high-performance, portable, extracorporeal equipment and vehicles with centrifuges and freezers required for rapid cooling, all working on an autonomous power supply). This program is necessary for maintenance of the indispensable qualified blood transfusion service.

Keywords: analysis; blood; disasters; donors; fresh frozen plasma; plasmapheresis; processing; renal failure; safety; transfusions; trauma

Prehosp Disast Med 2003:18:s(1)s33.

E-mail: hadjiyev_azad@yahoo.com

\section{Netherlands Military Blood Supply System \\ Charles C.M. Lelkens, SBB (ASCP) \\ Royal Netherlands Navy, Medical Director Netherlands, Military \\ Blood Bank}

The Netherlands civilian blood supply organization-the Sanquin Blood Foundation- recruits and screens all donors, performs the donor testing and produces the usual array of blood products. The Netherlands military blood supply system is built on the civilian organization in that it procures liquid red cells, FFP, and platelets from its civilian partner. Because of long, vulnerable supply lines and unpredictable needs during missions abroad, we adopted the use of frozen blood products as developed in the United States. The lecture will address the organization and missions of the Netherlands Military Blood Bank, the use of liquid and frozen blood products, means of transportation, and quality control. This expertise was used during missions in Bosnia (SFOR) and Afghanistan (ISAF) and is now currently in use in Iraq (SFIR) Finally, some recent research and development issues will be mentioned.

Keywords: Afghanistan; blood supply; Bosnia; frozen blood products; Iraq; military; Netherlands Military Blood Bank; Sanquin Blood Foundation

Prehosp Disast Med 2003:18:s(1)s33.

\section{Military Support to Civil Blood Programs and vCJD Deferral}

Donald R. Fipps

Chief Executive Officer, American Red Cross Blood Services

The role of the United States Armed Services Blood Program and its support to the United States civilian blood programs is presented. The military blood program primarily is self-supporting. The major support role the Armed Services Blood Program provides access to donors on military installations to civilian blood programs. The vCJD deferral policy of volunteer blood donors of American Red Cross and that of the United States Food and Drug Administration are reviewed and contrasted including the impact on prospective donors. The vCJD donor deferral rate for the American Red Cross went from $0.06 \%$ in March 2001 to $0.88 \%$ average by the end of 2002 . The rate continued to decline to $0.38 \%$ by December 2002 . 